\title{
Theological foundations for an effective Christian response to the global disease burden in resource-constrained regions
}

\section{Daniel W. O'Neilla}

\section{${ }^{a}$ MD, MA(TS), Managing Editor, CJGH; Assistant Professor of Family Medicine, University of Connecticut School of Medicine, USA}

\section{Introduction}

Given the global spread of Christianity, Christians are in a critical position to effect radical change in individuals, communities, and systems for human flourishing and confront the global disease burden, injustice, and resource disparity that exists in the world. The increasing presence, activity, and faithfulness of Christians among all peoples are necessary both for improved global health equity as well as the universal receiving of God's healing message. As an expanding movement, the Church has an increasing opportunity to define health, speak truth, provide care, make peace, cooperate, set priorities, and mobilize resources for maximum stewardship in low resource settings.

\section{Theological Correctives}

Understanding the theological roots of our Christian calling to be a healing community is vital to an effective and sustainable response to the current complexities of the global burden of disease in resource-constrained regions. Serving God who is the Healer, Comforter, Revealer, Reconciler, Sufferer, and Redeemer, we ground our response in the very character and actions of God. His justice and mercy is revealed in his actions in history and reflected in his call to social justice and mercy among the poor and afflicted (Ps 82:3; Prov 31:9; Jer 22:16; Mat 10:8). His call to stewardship of limited resources and opposition to greed and partiality is corrective to the waste and favoritism found in many global health systems
(Lev 19:15; Col 3:5). The high value of all human life, as made in the image of God, drives his people to protect and care for the most vulnerable populations of all races such as the underresourced, the unborn, the disabled, and the elderly at a time when materialist utilitarian ethics and eugenics are still persuasive forces in a world of exponential global population growth (Gen 1:27). ${ }^{1}$ Jesus' model of compassionate care-giving to individuals (sparrows) as well as populations (crowds) in Matthew 9 affirms both curative care and public health interventions toward human health and well-being, in contrast to purely scientific and rational approaches driven by data. The concept of new covenant modeled in God's character and laws counter an increasingly impersonal, technologically driven, and maldistributed $\$ 6.6$ trillion global healthcare industry (2 Cor 3:6).

\section{Global Inequalities and Opportunities}

There is an estimated shortage of 4.3 million health professionals globally, and 57 of the poorest countries in the world have disproportionately severe shortages. One billion people have no access at all to a trained heath worker. SubSaharan Africa has the lowest ratio of trained health workers and the greatest burden of disease. There are also marked inequities within each country with rural areas having the least access, underlining a call for more innovative systembased education to meet the demands. ${ }^{2}$

There is a similar maldistribution of Church resources among the unreached and unengaged 
peoples of the world. Over 2 billion people are living in 4,841 people groups with very few, if any, Christ-followers. ${ }^{3}$ The value added to the health of communities when the Church is planted is inestimable. As communities flourish, there is increased opportunity for the message of the saving grace of God to be heard. The ultimate divine goal and the end of history include every tribe, tongue, and nation in the manifest blessing of God's presence (Rev 7:9). The leaves of the currently inaccessible tree of life are for the healing of all nations without exception (Rev 22:2); so neglect of a systemic, cooperative movement to proclaim this healing message and plant healing communities everywhere is off track with the purposes of God. This can be thought of as a pursuit of universal health coverage.

As the Church has expanded globally, and has increasing human and material resources in the global South, she has positioned herself as a potential influencer for health, particularly among the poor where Christianity has "a breathtaking ability to transform weakness into strength."4 There are several ways in which the Church can lead in the contemporary global health enterprise. Each of these can be grounded in a robust theology informed by perspectives from the globalized Church.

\section{Defining Health}

The biblical definition of health is more expansive than the broad generalization from the World Health Organization (WHO) and involves restored wholesome relationships with:

1. self - image, self-care, purpose, meaning

2. others - peace-making, intimacy, family integrity, care for neighbor, equality, forgiveness, just societies

3. nature - environmental harmony, clean water, nutrition, medicines, micro and macroorganisms

4. the Creator - reconciliation, intimacy, and presence.
Health was the complete state described in Genesis 2 and corrupted in Genesis 3 and is the complete state to be gained in the consummation of a new heavens and earth (Isaiah 66:22; Rev 21:1). This state is best described with the Hebrew word shalom and can be approximated and pursued earnestly between these two bookends of history. ${ }^{5} \quad$ Worshiping communities seek to embody this principle of harmony, but have often fallen short in practice. When limited definitions of health are pursued, limited solutions are applied. Technical and material solutions to moral and spiritual problems are insufficient - they are not sustainable. The extent to which Christfollowers seek to flesh out the fullest definition of health in public conversations is the degree to which more effective and sustainable solutions will bring true lasting and widespread transformation to the nations.

If human flourishing necessitates a coalesceence of well-being in these four areas, then global health promotion requires engagement with concepts of identity and purpose, ecological stewardship, environmental dominion, economic consciousness, justice in governmental and nongovernmental systems, and reconciliation with God. The HIV pandemic highlights the multifaceted effects of such a disease burden on whole communities and nations - affecting economic, social, physical, and emotional livelihood - "an evil that tears at the very heart of human life on God's earth." This and the myriad of other diseases \& infirmities globally are tangible expressions of the corruption of the planet, the often indiscriminate and far-reaching effects of sin, and the inter-relatedness of all aspects of life. The divine healing intent toward human well-being and the purpose of the gathered community as the "face of healing in the world" are manifestations of His grace. ${ }^{7}$ The gospel provides a tangible expression of the only hope for complete healing, and the holistic mission of the Church must include engagement with all four of 
these areas to promote sustainable movements toward health and human flourishing.

\section{Speaking Truth}

As Revealer, God not only reveals Himself in the inspired Word, but also in the magnificence of the created order and through His Spirit. Creating the material world as knowable, He calls us to apply science and observation in a rational and empirical way to address human problems. Exploring the mysteries of causation and following evidence-based interventions is an exercise of dominion over the natural world. Discerning solid realities from myths, while at the same time not denying spiritual truths, creates a full-orbed approach to human affliction. As He spoke the world into existence and the Scriptures into writing, so He calls his people to speak the truth in love, to provoke one another toward love and good deeds, and to teach and admonish with all wisdom (Eph 4:15; Heb 10:24; Col 1:24). This means that skills, best practices, and reflections must be shared - growing and learning together toward the goal of God-honoring improvements in global health. ${ }^{8}$

As Creator, God mandated the naming of every creature, (Gen 2:19) and Jesus named demons (Mark 5:9), casting them out when necessary (Mark 16:17). Likewise, humans participate in identifying the cause of diseases, pursuing a cure or prevention when possible. These include more than pathogenic microorganisms or genetic mutations. Increasingly, the diseases of excess, addiction, and meaninglessness are affecting low and middle-income countries (LMICs) - the non-communicable diseases (NCDs). Three quarters of the 38 million deaths per year from NCDs are in LMICs. ${ }^{9}$ With economic development and globalization have come unhealthy food access, sedentary lifestyles, urbanization, motor vehicle trauma, disordered mental health, and markets of addictive substances. Biblical injunctions against gluttony, drunkenness, inordinate pleasures, abuse, violence, and laziness are truths that are increasingly recognized to have widespread health impact in communities. Neglect of nurture and bonding in infants also has major effects on public health. ${ }^{10}$ Naming these causes of chronic illness and disability by looking at the evidence and addressing the systems which promote them are part of fulfilling this mandate.

\section{Providing Care}

A sincere longing for personal and family well-being is an innate drive of humans who retain the image of God and long for wholeness, but is often exploited by the healthcare industry or denied by oppressive social, governmental, or religious systems. ${ }^{11,12}$ Caution must be given not to allow the idolatry of physical health and safety (the diseases we fear) or the idolatry of trusting in technological healthcare systems or governments or organizations (the things we trust) to replace abiding trust in the living "God who heals." (Ex $15: 26)^{5}$ Healthcare contextualized to the culture is of supreme importance, such as affirming African traditions of a dying process surrounded by family at home instead of a hospital. ${ }^{13}$ The care rendered by Jesus was exceptionally compassionate, personalized, indiscriminate, holistic, contextual, and self-sacrificial. He expects no less from His followers, who have unprecedented opportunity to retain and embody agape other-centeredness in contextualized care for the afflicted and work toward justice in all areas of life. After Pentecost, the Holy Spirit as Comforter empowers believers to comfort others with a care and concern that is unnatural and transformational (2 Cor 1:4). A more robust theological understanding of God as Healer will empower the Church to follow in Jesus' footsteps in the power of the Spirit as caregivers.

\section{Making Peace}

The Church's mandate to be a blessing to all nations, founded on the promise to Abraham in Genesis 12 , is a means to counter the curse on the 
earth and begin to restore shalom on the planet. Peacemaking is a divine movement to work amid corruption to restore shalom within individuals, between people and nations, with the environment, and with our Creator. As ministers of reconciliation, we participate in God's work of reconciling the whole of creation to Himself (2 Cor 5:18-19). Beyond proclaiming peace with God through Jesus Christ, this call to the Church includes mental and physical health promotion and care, and extends to promote peace in areas of tribal, gender, class, and ethnic conflict. Those who sow in peace reap a harvest of righteousness (justice) in communities impacted by their presence (James 3:18). This peace is not made with principalities and powers bent on destruction and the devaluation of human life such as pathogenic microorganisms and unjust oppressive systems. Rather, peace is made with that which is redeemable: restored self-identity and the discipline of self-care; favorable pathogens in our microbiome and soil; the land's crops and animal resources; geological and ecological balances; right relationships in our family and neighbors; witness in communities; affirmation of wholesome ethnic traditions and international harmony to reduce civil conflict.

\section{Cooperating Broadly}

Though the Church is designed to embody the fullness of truth, she does not have a monopoly on the truth. There was wisdom in the men of the east in Solomon's day (1 Kings 4:30), the Queen of Sheba was thought able to judge the generation of Jesus' day (Matt 12:42), and the Cretan poets were true in their self-assessment of unhealthy practices in Paul's day (Titus 1:12-13). If God can call Nebuchadnezzar His servant (Jer 25:9) and move the heart of Cyrus (Ezra 1:1), could He not also use governments and other global health actors to accomplish His purposes for the health of the nations? Could the Church consider greater levels of cooperation to help build health systems through ministries of health in LMICs? ${ }^{14}$
Lancet published a series of articles in June 2015 that showed the important role the Church plays in healthcare delivery, particularly in areas poorly served by governmental resources. They called for greater cooperation and mutual recognition between governmental organizations and faith-based organizations (FBOs). ${ }^{15}$ Though Jesus recognized that the people of this world are more shrewd than the people of the light (Lk 16:8), He also called His disciples to be as shrewd as serpents and innocent as doves (Mt 10:16). There are times when the wisdom of the world uninformed by God's Spirit and Word will be foolishness (1 Cor 1:20-25) and that powers designed to promote human flourishing may be corrupted and end up constraining it. However, the Church must witness to those powers, working, in the words of N.T. Wright, cheerfully "with the grain of good will" with people of all faiths or no faith in the art of "collaboration without compromise and of opposition without dualism." 16 This requires deep trust in the sovereignty and immanence of God in all aspects of life, relying not on human wisdom alone but on God's power to see true transformation and reconciliation (1 Cor 2:5).

Interdenominational dialog and recognition of the charismatic nature of the global Church in the majority world will be necessary for a unified approach to transformation. Understanding that among the grassroots poor in Asia, for example, Christ is seen not as political liberator as in Latin American liberation theology or among the elites, but as liberator from fear and fatalism caused by centuries of internalizing the law of karma, from fear of spirits, from demonic oppression (perceived or real), and through healing of diseases - especially when access to modern health care is limited or unattainable. ${ }^{17}$ Offering what Samuel Escobar called "transforming service" validates and confirms the truth and fullness of the gospel message. ${ }^{18}$ 


\section{Setting Priorities}

Jesus modeled the priority of touch and the spoken word in healing the sick and integrated the redemption of the whole person - not resorting to its reductionist parts, nor to purely technical solutions. Primary Health Care, embraced in the 1978 Alma Ata Declaration through the influence of the Christian Medical Commission, and reiterated in 2008 by the WHO, can be embraced and enhanced for greater global distribution. ${ }^{19}$ Christians can continue to influence goal-setting as they did with the Millennium Development Goals (MDGs) and become more engaged to inform decisions for the next 15 years and beyond.

'This year, the new Sustainable Development Goals (SDGs) bring a new level of sophistication in seeking to be inclusive of many interrelated elements that contribute to human health, development, and also to planetary wellbeing. Focusing on the complexities of systems, this goal-setting is explicitly calling for "transforming our world." 20 To presume this can be accomplished without the transforming presence of Christ and his followers is wishful thinking.

While both the WHO definition of health and the SDGs seem utopian, there is value in setting goals for human flourishing and ecological stewardship as part of the cultural mandate of Genesis 1:27-28. Cooperating with all global health actors with similar goals, Christians can participate in praying and acting toward these preferable futures. The third SDG is to "ensure healthy lives and promote well-being for all at all ages." 21 This includes continuation of the MDGs for reduced maternal and child mortality, access to essential medications, and control or eradication of infectious diseases, but adds goals to reduce noncommunicable diseases, mental illness, tobacco and drug abuse, environmental hazards, and to enhance work-force and health systems along with global health threat preparation. Resources, such as the Disease Control Priorities (DCP-3), help countries improve health using evidence-based approaches in low-resource settings. ${ }^{22}$ Setting priorities based on Jesus' statement, "It is not the well who need a doctor but the sick" (Luke 5:31) and Paul's ambition to make Christ known where He is not (Rom 15:20) will help us focus on the poorest, most vulnerable, and most infirm among global populations and the people-groups who have not yet experienced the presence of His people or His word in their own language and cultural context. This can be thought of as working toward global health equity.

\section{Mobilizing Resources for Maximum Stewardship in Limited Resources Areas}

God has graciously provided a collective abundance of resources on the planet, but they are just not distributed equally or fully appropriated. Just as material deprivation can lead to malnutrition, impaired immunity, crime, and disease; overabundance of resources can be harmful to body, mind, and spirit. This unequal distribution may be the results of oppression, corrupt systems, climate change, personal sin, etc., but it also may be part of the sovereign plan of God to call his people to exercise the grace of giving (2 Cor 8:14-15) and to practice justice and mercy in the world as a sign of the kingdom (Mat 11:5). Would eradication of poverty undermine Jesus' statement that we will always have the poor with us (John 12:8)? Are not the two extremes worth opposing (Prov 30:8-9)? Is not some degree of human deprivation beneficial: to feel the need for redemption, to seek interdependent relationships, to practice patience, and to respond to good news with gratitude and long for a better hope? After healing the crowds, Jesus spoke of the blessings that reside with the poor and gave warnings to the rich that both may become a blessing to the nations (Luke 6:17-26).

As Sustainer, God can mobilize unforeseen resources, but the injustice of an estimated $6 \%$ 
fraud and embezzlement of global Christian resources must be faced. ${ }^{23}$ Participating in training healthcare professionals for retained service in LMICs helps meet the vast shortages and multiplies knowledge, as well as serving as an opportunity for mentoring. Engaging in advocacy at the government level to create laws favorable to enhanced public health and justice is a calling to witness to the powers and cooperate with reforming systems for human flourishing. ${ }^{24}$ Embracing the public health movement to utilize community health workers to provide greater access to care can be a way to distribute Christfollowers into suffering communities. As extensions to the reach of health knowledge, these empowered workers can move the locus of control from a minority of highly educated to the "strengthened hands of the poor" (Ezek 16:49), and through approaches such as Community Health Evangelism create greater witness to the truth of causes and cures of disease and the application of the gospel of peace.

\section{Conclusion}

Expanding Christian communities throughout the world are indeed in a critical position to be faithful witnesses to the God who heals, to be salt and light to a health care industry that desperately needs to provide affordable, accessible, compassionate whole-person care to every population, and to influence policy and practice in global health toward equity and justice. The very character and nature of God and the call to those who follow Him inform and inspire intelligent action, compassionate and comprehensive service, and effective results for human flourishing. Though often unrecognized and underappreciated, the Church needs to press on with increased confidence and vigor - standing in the gap to care and advocate for underserved populations, witnessing to corrupt systems for the greater good, extending God's healing presence, and actively sending multipliers across cultures into all peoples until all things are made new.

\section{References}

1. Stern AM. Eugenic nation: faults and frontiers of better breeding in modern America, $2^{\text {nd }}$ Ed. Oakland: University of California Press. 2016. 1-27.

2. Crisp N, Chen, L. Global supply of health professionals. New England Journal of Medicine 2014; 370 (10): 950-956. http://dx.doi.org/10.1056/NEJMra1111610

3. Joshua Project. Global Statistics [2015]. Available from: http://joshuaproject.net/global_statistics.

4. Jenkins P. The next Christendom: the coming of global Christianity, $3^{\text {rd }}$ ed. New York: Oxford University Press. 2011. 276.

5. Myers BL, Dufault-Hunter E, Voss IB, editors. Health, healing and shalom: frontiers and challenges for Christian health missions. Pasadena, CA: Wm Carey Library. 2015.

6. Wright $\mathrm{CJH}$. The mission of God: unlocking the Bible's grand narrative. Downer's Grove, IL: IVP Press. 2006:168-9;437.

7. Swartley WH. Health, healing and the church's mission: biblical perspectives and moral priorities. Downer's Grove: IVP Academic. 2012. 25-42.

8. Larson HE \& O'Neill D. Collective wisdom and practical knowledge: the new Christian Journal for Global Health. Christian Journal for Global Health, 2014; 1(1) http://dx.doi.org/10.15566/cjgh.v1i1.26

9. World Health Organization. World Fact Sheet. Noncommunicable Diseases. [Cited 2015, January]

Available from

http://www.who.int/mediacentre/factsheets/fs355/en/

10. World Health Organization, Commission on Social Determinants of Health. Closing the gap in a generation: health equity through action on the social determinants of health. Final Report of the Commission 
on Social Determinants of Health. Geneva: World Health Organization. 2008, 50-9.

11. Kotter-Gruhn D, Wiest M, Zurek PP, Scheibe S. What is it we are longing for? Psychological and demographic factors influencing the contents of Sehnssucht (life longings). Journal of Research in Personality 43 (3), June 2009: 428-37. http://dx.doi.org/10.1016/j.jrp.2009.01.012

12. Waitzkin H. The second sickness: contradictions of capitalist health care. (Lanham, MD: Rowman \& Littlefield) 2000, 7.

13. Bujo B. African theology in its social context. Eugene, OR: Wipf \& Stock. 1992: 122-9.

14. Pfeiffer J, Johnson W, Fort M, Shakow A, Hagopian A, Gloyd S, et al. Strengthening health systems in poor countries: a code of conduct for nongovernmental organizations. American Journal of Public Health. Dec 2008; 98 (12), 2134-40.

http://dx.doi.org/10.2105/AJPH.2007.125989

15. Duff JF, Buckingham WW. Strengthening of partnerships between the public sector and faith-based groups. Lancet 2015; 386(10005). http://dx.doi.org/10.1016/S0140-6736(15)60250-1

16. Wright NT. Surprised by hope. New York: Harper One; 2008. p. 269.

17. Chan S. Grassroots Asian theology: thinking the faith from the ground up. Downers Grove, IL: IVP; 2014. p. 103.
18. Escobar S. The new global mission: the Gospel from everywhere to everyone. Downers Grove, IL: IVP; 2003. p. 143-54.

19. Litsios S. The Christian Medical Commission and the development of the World Health Organization's primary health care approach. American Journal of Public Health 2004, Nov 11; (11):1884-93. http://dx.doi.org/10.2105/AJPH.94.11.1884

20. United Nations. Sustainable Development Knowledge Platform. Available from: https://sustainabledevelopment.un.org/post2015/transfo rmingourworld

21. United Nations. Goal three targets. Sustainable development. Available from: http://www.un.org/sustainabledevelopment/health/

22. Disease control priorities, $3^{\text {rd }}$ Edition. (2015). Department of Global Health, University of Washington. World Bank Group Publications. Available from http://www.dep-3.org/

23. Johnson T, Zurlo G, Hickman A. Embezzlement in the global Christian community. The Review of Faith and International Affairs 13(2). June 2015. http://dx.doi.org/10.1080/15570274.2015.1039302

24. Davis R. What about justice? Toward an evangelical perspective on advocacy in development. Transformation, 26(2), 2009. 89-103. http://dx.doi.org/10.1177/0265378809103385

Peer Reviewed

Competing Interests: None declared.

Disclosures: The contents of this article were presented by the author at the International Conference on Christian Response to Global Heath Issues at the Universitas Pelita Harapan on December 3, 2015 in Jakarta, Indonesia and published in the conference proceedings.

Correspondence: Daniel O’Neill, dwoneill@cjgh.org 
Cite this article as: O'Neill DW. Theological foundations for an effective Christian response to the global disease burden in resource-constrained regions. Christian Journal for Global Health (May 2016), 3(1): 310.

(C) O'Neill DW This is an open-access article distributed under the terms of the Creative Commons Attribution License, which permits unrestricted use, distribution, and reproduction in any medium, provided the original author and source are properly cited. To view a copy of the license, visit http://creativecommons.org/licenses/by/3.0/

www.cjgh.org 